\title{
Bright lights: disclosures from the optical, spectroscopic and chromatographic characterization of a 19th century Portuguese sedan chair
}

\author{
Catarina Miguel ${ }^{1, *}$, Ana Raquel Bispo², Beatriz Gonçalves², Diogo Marques², Inês Faria², \\ Maria das Dores Macias², Nuno Neves², Nádia Silva², Vanessa Rocha², António Santos Silva ${ }^{3}$ \\ ${ }^{1}$ HERCULES Laboratory, Institute for Advanced Studies and Research, Évora University, Largo Marquês de \\ Marialva 8, 7000-676 Évora, Portugal \\ 2 Fundação Ricardo Espírito Santo Silva/Escola Superior de Artes Decorativas, Rua João de Oliveira Miguens 80, \\ 1350-187 Lisboa, Portugal \\ ${ }^{3}$ Laboratório Nacional de Engenharia Civil, Avenida do Brasil 101, 1700-066 Lisboa, Portugal \\ *cpm@uevora.pt
}

\begin{abstract}
The Fundação Ricardo Espírito Santo Silva (FRESS) has the mission of defend, train, study, develop and implement Portuguese Fine Arts in Portugal. This paper reflects the process of Conservation-Restoration training, where students apply the most recent analytical techniques to the characterization of artwork towards enabling and supporting conservation intervention. In this study, the materials used to produce a 19th century sedan chair were characterised by optical microscopy, spectroscopic (SEM-EDS, $\mu$-Raman and FTIR-imaging) and chromatographic (HPLC-DAD/MS) techniques. The use of natural and synthetic dyes was identified in textiles found inside the chair, including cochineal, brazilwood and fuchsine. Several paint layers with different colours and compounds, such as barite, calcium carbonate, lead white, hematite and Prussian blue, were identified in the external painted wood surface of the chair. The variety of identified materials, interspersed between layers of animal glue, reflects the different interventions that took place on the chair over time, supporting the intervention strategies reported/prescribed for the conservation-restoration procedure.
\end{abstract}

Luzes com brilho: revelações das caracterizações ópticas, espectroscópicas e cromatográficas de uma liteira portuguesa do século XIX

\section{Resumo}

A Fundação Ricardo Espírito Santo Silva (FRESS) tem como missão a formação, estudo e salvaguarda das Artes e Ofícios Portugueses. Este trabalho reflete a abordagem seguida na formação em Conservação e Restauro, onde os alunos têm acesso a técnicas analíticas de ponta para a caracterização de Obras de Arte. Os materiais usados para produzir uma liteira do séc. XIX foram caracterizados por microscopia óptica (OM), técnicas espectroscópicas (SEM-EDS, FTIR-imaging e $\mu$-Raman) e cromatográficas (HPLC-DAD/MS). Os resultados revelaram a presença de corantes naturais e sintéticos nos têxteis do interior da liteira (cochinilha, pau-brasil e fucsina). A análise do exterior da liteira revelou a presença de várias camadas estratigráficas com diferentes cores e composições (por exemplo, barite, carbonato de cálcio, branco de chumbo, hematite e azul da Prússia). A variabilidade de materiais intercalados por camadas de cola animal sugere a existência de diferentes intervenções na liteira, o que serviu de suporte às estratégias de Conservação e Restauro adoptadas pelos alunos finalistas da FRESS.

\section{Keywords}

Sedan chair

Dyes

Pigments

Spectroscopy

Chromatography

\section{Palavras-chave}

Liteira

Corantes

Pigmentos

Espectroscopia

Cromatografia 


\section{Introduction}

Artwork conservation and restoration are research areas that highlight the importance of interdisciplinary teams and approaches. If past conservator-restorers were expected to be highly qualified and skilled technicians, today they are trained to enhance their existing skills by integrating and coordinating interdisciplinary teams of art historians, chemists, conservation scientists, physicists, etc. With the aim of providing high quality training, the Fundação Ricardo do Espírito Santo Silva (FRESS) developed its education programme by including the teaching of traditional Portuguese fine art techniques, alongside the best conservation-restoration approaches as well as teaching scientific analytical techniques applied to characterization of cultural heritage. Collaboration with highly qualified institutions for the study of cultural heritage, such as the Laboratório Nacional de Engenharia Civil (LNEC) and the HERCULES Laboratory of Évora University, are paramount, allowing students to participate in research projects characterizing the materials and techniques used for production of artwork which will in turn be restored during final year projects of the Conservation-Restoration undergraduate courses. This paper presents one example of such strategy, which is related to the materials study performed on 19th century sedan chair.

The use of sedan chairs as a mode of transport was introduced to Europe during the 16th century by Portuguese and Spanish explorers, following their journeys to China [1]. During the 17th century, they became commonly used for public rental and transportation of contagious disease victims [1]. Through the 19th century, sedan chairs were used in Hospitals mainly for the transport of patients and/or pregnant women. The sedan chair presented here is part of the Portuguese Hospital de São José's collection and dates to the beginning of the 19th century. It is a vertically elongated dark painted wooden box containing a seat, two lateral windows and a front door with a window. Two removable poles placed sideways on metal brackets enabled its transportation. Two or more men (depending on the passenger weight) were needed to carry the chair, with the help of leather straps hanging from their shoulders, Figure 1.

There are no reports of previous interventions for this particular sedan chair. Nevertheless, the fact that it might have been intensively used to transport patients lets us believe that several past conservation interventions might have occurred, especially with regard to the traces of previously used textiles to line the interior. Furthermore, some of the lacuna present on the external painted surface enabled the study of underlayers pertaining to different external surface colour of the sedan chair. This aroused an extreme interest to analyse the composition of these stratigraphic colour layers and to infer the original colour of the sedan chair and several improvements or changes that it might have endured over time both on its interior and exterior components.
The practice of dyeing textiles dates back to the ancient civilizations. Textiles recovered from archaeological excavations allowed the identification of natural dyes used for colouring, such as purple and red insect dyes identified in Roman Egyptian archaeological textiles [2], or the application of indigo for the production of the Paracas mantles used for covering the deceased [3]. Other natural dyes were used for textile decoration, like cochineal and brazilwood lakes. Cochineal is a scale insect that produces carminic acid (with a core anthraquinone structure linked to a glucose unit) found in the body and eggs of the females. It has been widely used as bright-red dye on paintings and dyed textiles for centuries [2]. Use of brazilwood (namely brazilein - the oxidized flavonoid molecule extracted from Caesalpinia species) flourished as a pigment after the discovery of Brazil in 1500 [2]. These red dyes were used for centuries prior to the discovery of new synthetic dyes in the mid19th century. After the serendipitous discovery of the first synthetic dye - mauveine - by W. H. Perkin in 1856, new synthetic dyes, which were less expensive and more resistant to photodegradation, started to replace the use of natural dyes, which were found to be more expensive and, in some cases, less stable [4]. Fuchsine, a synthetic basic aniline dye, was first synthesised by A. H. von Hofmann in 1858, although it was François-Emmanuel Verguin, who also developed its synthesis at the same time in France and who first registered the patent [5]. Its bright magenta colour and stability made fuchsine one of the most widely used basic dyes of that time. Although synthetic dyes were widely used for dyeing textiles from the mid-19th century onwards, natural dyes can still be found in 19th and 20th century dyed wood and textiles [6].

A colour paint is essentially composed of a colourant (such as a pigment or an organic dye) and a binder (responsible for the cohesion of the pictorial layer and for its adhesion to the support). Other additives may be used to improve the mechanical properties of the paint,

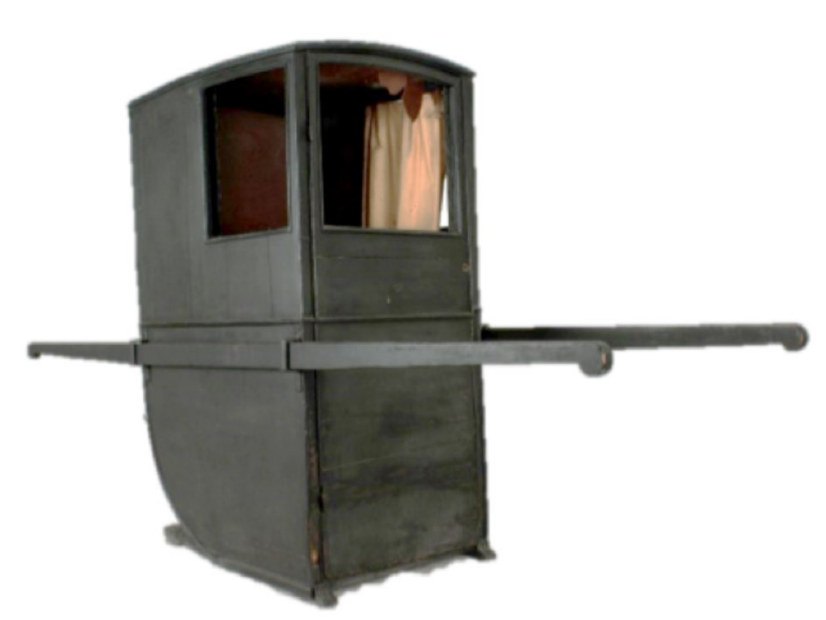

Figure 1. Sedan chair from the Hospital de São José collection (height: $143 \mathrm{~cm}$; width: $74.5 \mathrm{~cm}$; depth: $88.5 \mathrm{~cm}$; clothesline: $278 \mathrm{~cm})$. Photo: ESAD-FRESS. 
as well as the film opacity. Lead white (a basic lead carbonate hydroxide, $\left.2 \mathrm{PbCO}_{3} \cdot \mathrm{Pb}(\mathrm{OH})_{2}\right)$ can be found in nature in form of the rare mineral hydrocerussite, but it is more commonly synthesised. There are references for the production of lead white from Antiquity onwards, when it became the white pigment par excellence for art history paintings [7]. Its use was replaced by other less hazardous white pigments in the 19th and 20th century. The use of calcite (calcium carbonate, $\mathrm{CaCO}_{3}$ ) as a white pigment has been identified in Greek and Roman art, while its use as extender dates to earlier time [8]. Barite (barium sulphate, $\mathrm{BaSO}_{4}$ ) is a mineral found in nature together with calcite and other sulphide minerals. Its synthesis and wide spread use as white pigment as extender dates back to 19th century [8]. Hematite $\left(\mathrm{Fe}_{2} \mathrm{O}_{3}\right)$, an iron oxide commonly found in nature, is probably the most widely used red pigment in art history and its use dates back to the Palaeolithic period [8]. During the Baroque period, hematite can be commonly found in the bole of the preparation layer for gilding in painting, sculpture and altarpieces. Blue colour is also widely present across art history of paintings. The mineral lapis lazuli was the most precious and expensive blue pigment of medieval period. In late medieval paintings, it began to be replaced by azurite, a less expensive pigment which is also found in nature [9]. As chemistry developed, new and less expensive pigment syntheses were introduced. Prussian blue, an hexacyanoferrate pigment $\left(\mathrm{Fe}_{4}\left[\mathrm{Fe}(\mathrm{CN})_{6}\right]_{3} \cdot \mathrm{xH}_{2} \mathrm{O}\right)$, was first synthesized by J. J. Diesbach and J. C. Dippel at the beginning of 18th century, and from then on until the 19 th century, it was a widely used blue pigment [8].

In this research, the textiles and wood structure of a sedan chair from the 19th century were characterized by optical, chromatographic and spectroscopic techniques. The experimental work was developed by final year students of the Conservation and Restoration course at FRESS (Ana Raquel Bispo, Beatriz Gonçalves, Diogo Marques, Inês Faria, Maria das Dores Macias, Nuno Neves, Nádia Silva and Vanessa Rocha), under the supervision of Catarina Miguel and António Santos Silva, with the help of the technical staff from the HERCULES Laboratory. Optical microscopy (OM) allowed identification of wool and silk textiles, while chromatographic techniques (HPLC-DAD/MS) enabled the identification of cochineal, brazilwood and fuchsine dyes. OM also allowed the identification of pinewood through examining the wood structure. The microscopic observation of the paintwork cross-section revealed the presence of several layers that might reflect different interventions on the decorative paintings of the sedan chair over time. Electron microscopy coupled with energy dispersive X-ray spectrometry, Raman microscopy and Fourier Transform Infrared spectroscopy with imaging detection allowed the characterization of pigments, extenders and binders, highlighting what could have been the original colour of this sedan chair - a deep-bright Prussian blue colour.

\section{Materials and methods}

Optical microscopy (OM), high performance liquid chromatography with diode array detection/mass spectrometry detection (HPLC-DAD/MS) and scanning electron microscopy coupled with energy dispersive X-ray spectrometry (SEM-EDS) were used for characterization of the textiles. To determine the composition of wood and paint layers OM, SEM-EDS, Raman microscopy ( $\mu$-Raman) and Fourier Transform Infrared spectroscopy with imaging detection (FTIR-imaging) were used.

\section{Sampling}

Two samples of textiles were collected in order to establish a possible application chronology of these textiles to the sedan chair. Sample 1 was taken from the seat cover; while sample 2 was taken from the anchoring zone of the door trim panel. A micro-sample collected from the external wood painting was mounted as a crosssection using an epoxide resin (EpoFix kit, Struers).

\section{Extraction of dyes from textile fibre}

Dyed fibre samples weighing approx. $2.0 \mathrm{mg}$ were placed in vials and $1.0 \mathrm{~mL}$ of $0.1 \%$ EDTA solution in $\mathrm{H}_{2} \mathrm{O} / \mathrm{DMF}(1: 1, \mathrm{v} / \mathrm{v})$ was added. The vials were closed and kept at $100{ }^{\circ} \mathrm{C}$ for $30 \mathrm{~min}$. Vials were then cooled to room temperature and excess solvent removed by vacuum. Dried samples were re-dissolved in $250 \mu \mathrm{L}$ of $\mathrm{MeOH} / \mathrm{H}_{2} \mathrm{O}$ $(1: 1, v / v)$ and filtered through a $0.45 \mu \mathrm{m}$ PTFE filter.

\section{Optical microscopy}

A dark field microscope Leica DM2500M equipped with a Leica MC 170HD camera was used for the examination of textile and paint cross sections. The images were recorded under visible light and UV radiation, produced by a high pressure burner $103 \mathrm{~W} / 2$ UV lamp with an excitation filter BP 340-380, a 400 dichromatic mirror and a suppression filter Lp425, size K. A Leica $\mathrm{M} 205 \mathrm{C}$ stereomicroscope with a zoom range of $7.8 \times$ to 160x equipped with a Leica DFC295 camera and external illumination by optical fibres was used for the longitudinal observation of the fibres.

\section{SEM-EDS}

SEM-EDS analyses were performed with a scanning electron microscope HITACHI $3700 \mathrm{~N}$ coupled to an energy dispersive X-ray spectrometer Bruker Xflash 5010. The analyses were made at $20 \mathrm{kV}$ with variable pressure (40 Pa).

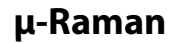

A Raman spectrometer HORIBA XPlora equipped with a diode laser of $28 \mathrm{~mW}$ operating at $785 \mathrm{~nm}$, 
coupled to an Olympus microscope was used for the analysis of the paint cross sections. Raman spectra were acquired in extended mode in the $100-2000 \mathrm{~cm}^{-1}$ region. The laser was focused with a Olympus $50 \times$ lens, with 1.1-2.8 $\mathrm{mW}$ laser power on the sample surface (10 seconds of exposure, 10 cycles of accumulation).

\section{FTIR-imaging}

An infrared spectrometer Bruker Hyperion 3000 equipped with a FPA detector cooled with liquid nitrogen and a $20 \times$ ATR objective with a Ge crystal of $80 \mu \mathrm{m}$ diameter was used. The infrared spectra were acquired with a spectral resolution of $4 \mathrm{~cm}^{-1}, 64$ scans, in the $4000-900 \mathrm{~cm}^{-1}$ of the mid infrared region. For the analysis of each sample an infrared image (imaging) composed of $64 \times 64$ pixels was generated, each pixel corresponding to an infrared spectrum. In total 4096 spectra were generated. The integration of an absorption band over the mapped areas allowed the visualization of its intensity distribution. For the analysis of textile fibres, a single point MCT detector cooled with liquid nitrogen and a 20x ATR objective with a Ge crystal of $80 \mu \mathrm{m}$ diameter were used. The infrared spectra were acquired with a spectral resolution of $4 \mathrm{~cm}^{-1}$, 64 scans, in the $4000-650 \mathrm{~cm}^{-1}$ of the infrared region. For both textiles' analyses, $\mathrm{CO}_{2}$ absorption at circa 2400$2300 \mathrm{~cm}^{-1}$ was removed from the acquired spectra (4000$\left.650 \mathrm{~cm}^{-1}\right)$.

\section{HPLC-DAD/MS}

Analyses were carried out with a LCQ Fleet Thermo Finnigan mass spectrometer equipped with an electrospray ionization source, and using an ion trap mass analyser. The conditions of the MS analysis were capillary temperature of $300{ }^{\circ} \mathrm{C}$; source voltage of $5.0 \mathrm{kV}$, source current of $100.0 \mu \mathrm{A}$ and capillary voltage of $-7.0 \mathrm{~V}$ in negative ion mode and $3.0 \mathrm{~V}$ in positive ion mode. Analytes were detected in full MS mode: in negative ion mode two segments were used, $10.0 \mathrm{~V}$ CID from 0-12 min and 30.0 V CID from 12-30 min; in positive ion mode $30.0 \mathrm{~V}$ CID was used from 0 to $30 \mathrm{~min}$. The mass spectrometer was coupled to an HPLC system with an autosampler (Surveyor Thermo Finnigan) and a diode array detector (DAD). The analytical column was a reversed phase Zorbax Eclipse XDB C18 (Rapid Resolution, particle size $3.5 \mu \mathrm{m}, 150 \mathrm{~mm} \times 4.6 \mathrm{~mm}$ ). Column temperature was set to $30^{\circ} \mathrm{C}$ and tray temperature to $24^{\circ} \mathrm{C}$. The chromatographic separation was performed with the mobile phase flow rate of $0.2 \mathrm{~mL} \mathrm{~min}^{-1}$ and by injecting $5 \mu \mathrm{L}$ of sample. The mobile phase was composed of $0.1 \%(\mathrm{v} / \mathrm{v})$ formic acid solution (A) and acetonitrile (B) using the following elution programme: 0-63\% B (0-14 min), 63-90\% B (14-25 min), $90 \%$ B (25-30 $\mathrm{min})$. DAD detector was scanning from 190 to $800 \mathrm{~nm}$.

\section{Results}

\section{Textiles}

\section{Fibres and mordants}

Through stereomicroscopical observation, it was possible to verify that sample 1 is heterogeneously coloured with purple (as some yellow-brownish fibres can be seen underneath and protruding through purple fibres), whereas the second textile (sample 2) is homogeneously coloured with reddish stripes on a yellow background, Figure 2.

Both textiles were produced using protein fibres, following the so-called taffeta weave, where the weft is inserted through the warp alternatingly (going over one, then under the next, and so on) and forming a threadcrossing pattern. SEM images of isolated fibres of sample 1 display the surface pattern of fine woollen fibres,
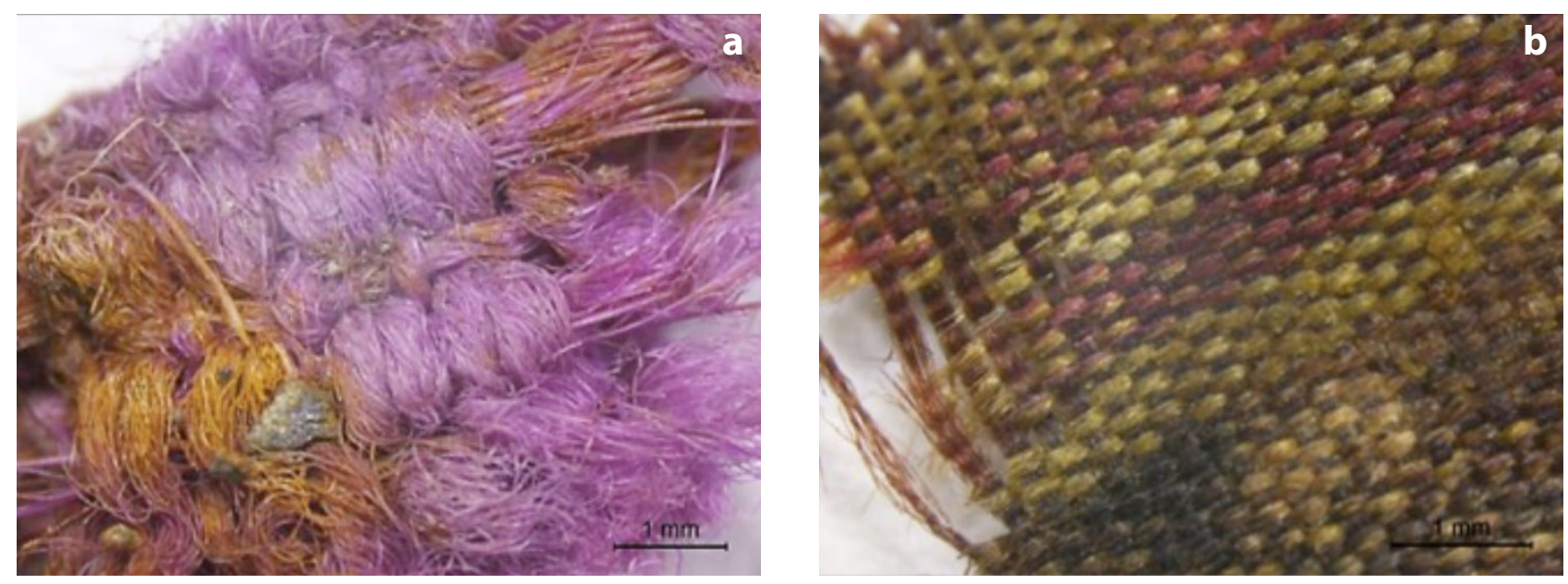

Figure 2. Optical microscopy images of the textiles from the inside of the sedan chair: $a$ ) sample $1 ; b$ ) sample 2. 

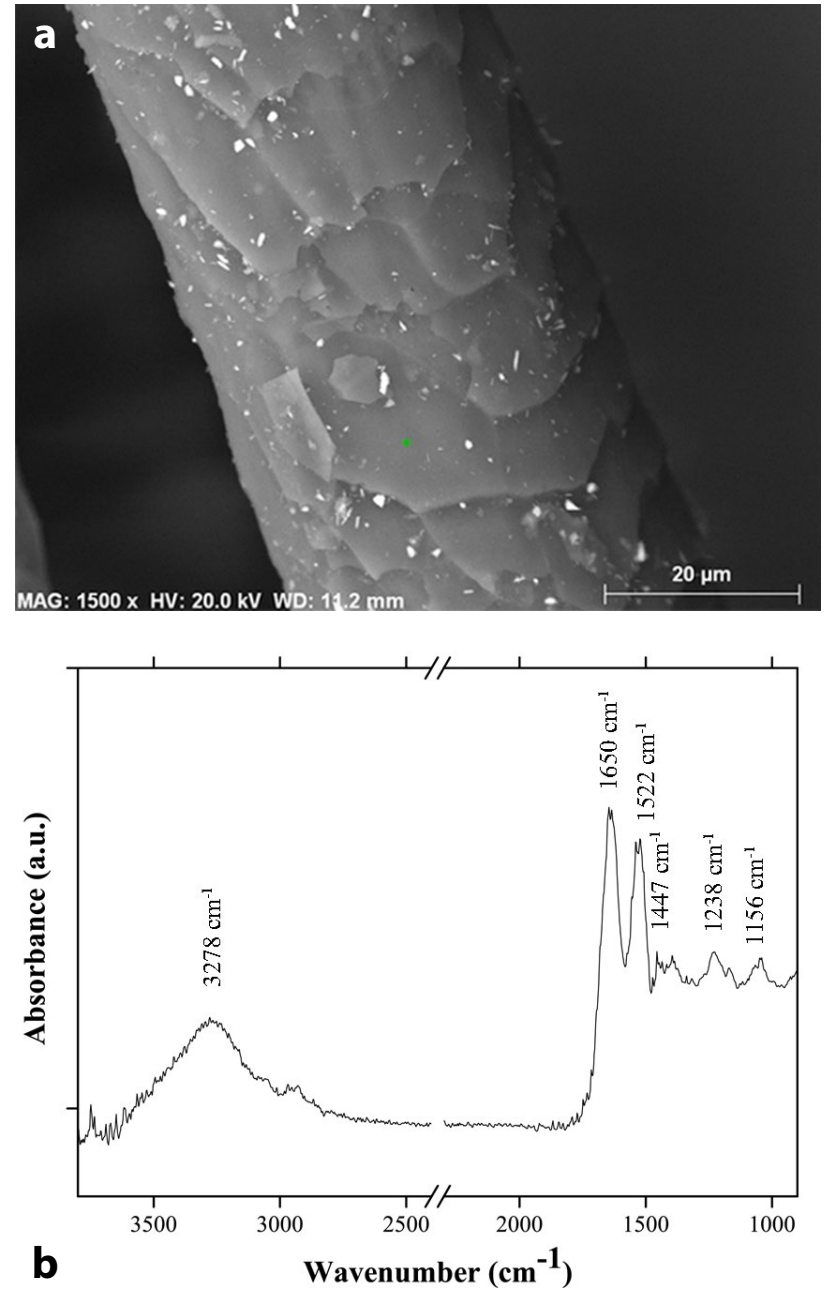

Figure 3. a) SEM image of a fibre collected from sample 1 with the characteristic wool fibre scale pattern; $b$ ) FTIRATR spectrum of sample 1 displaying the characteristic wool absorption bands.

consisting of a characteristic irregularly weaved mosaic scale pattern as the result of keratin growth [10], Figure 3. The bright spots on the fibres are related to the use of an aluminium-based mordant, corroborated by EDS analysis, which confirmed the presence of aluminium, sulphur and potassium in these spots, related to the use of alum (Figure 3). FTIR-ATR analysis of sample 1 showed the characteristic absorption bands of wool, namely the $\nu(\mathrm{O}-\mathrm{H})$ at $3278 \mathrm{~cm}^{-1}$, the absorption of Amide I at $1650 \mathrm{~cm}^{-1}$, the absorption of Amide II at $1552 \mathrm{~cm}^{-1}$, the $\delta(\mathrm{C}-\mathrm{H})$ at $1447 \mathrm{~cm}^{-1}$ and the $\nu(\mathrm{C}-\mathrm{N})$ at 1238 and $1156 \mathrm{~cm}^{-1}$ [11], Figure 3 .

SEM imaging of sample 2 revealed smooth surface pattern of silk fibres [10], Figure 4. Contrary to what was observed in sample 1, the mordant in sample 2 is partially deposited on fibres' surfaces as bright aluminium, sulphur and potassium plates (Figure 4). FTIR-ATR analysis of sample 2 presented characteristic absorption bands of silk, namely the $\nu(\mathrm{O}-\mathrm{H})$ at $3277 \mathrm{~cm}^{-1}$, the absorption of Amide I at $1621 \mathrm{~cm}^{-1}$, the absorption of Amide II at $1516 \mathrm{~cm}^{-1}$ ad the absorption of Amide III at $1260 \mathrm{~cm}^{-1}$ [11], Figure 4 .
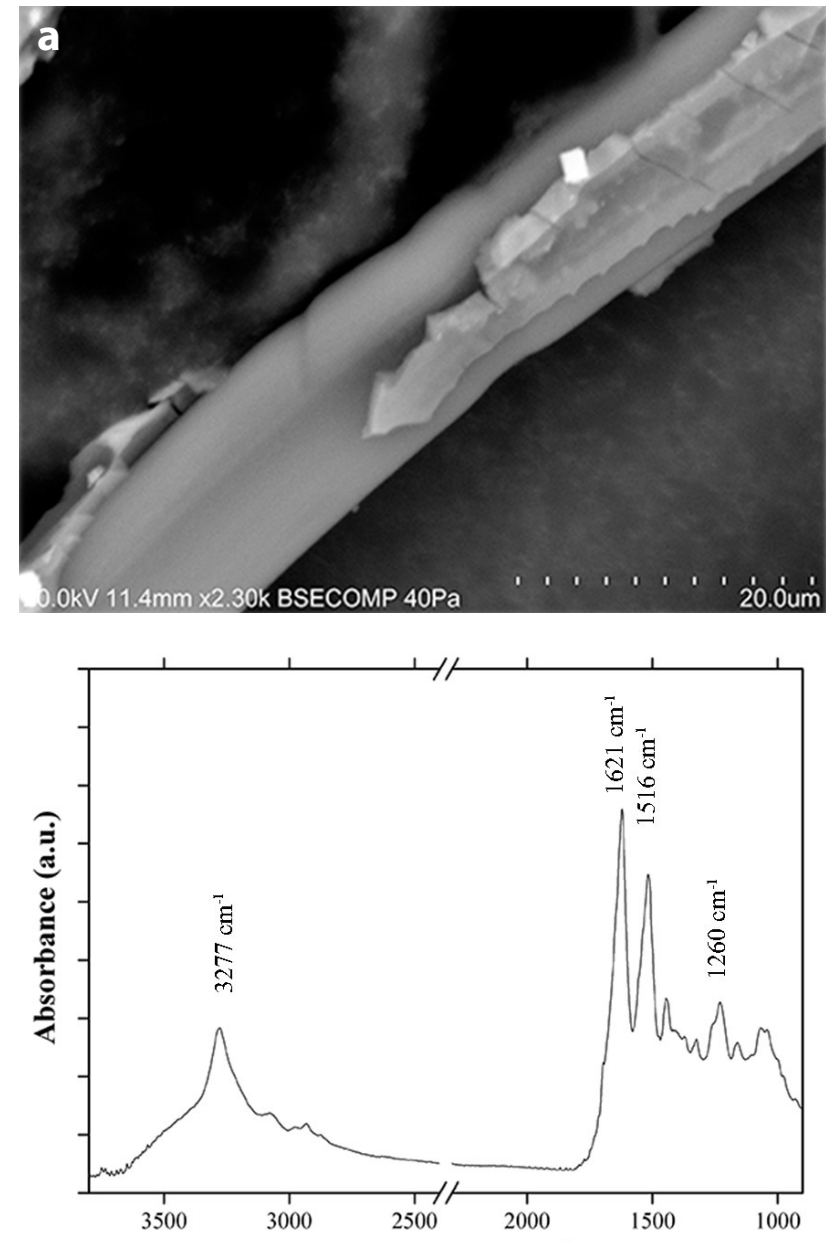

b Wavenumber $\left(\mathrm{cm}^{-1}\right)$

Figure 4. a) SEM image of a fibre collected from sample 2 with the characteristic silk fibre scale pattern; $b$ ) FTIRATR spectrum of sample 2 displaying the characteristic silk absorption bands.

Dyes

HPLC-DAD/MS analysis of sample 1 (Figure 5 and Table 1) identified the presence of pararosaniline $\left(t_{R}=16.75 \mathrm{~min}\right)$, rosaniline $\left(t_{R}=17.38 \mathrm{~min}\right)$, magenta II $\left(t_{R}=17.99 \mathrm{~min}\right)$ and neofuchsine $\left(t_{R}=18.59 \mathrm{~min}\right)$, reflecting the use of basic fuchsine, which is a synthetic dye [12].

HPLC-DAD/MS analysis of sample 2 (Figure 6 and Table 2) revealed the presence of carminic acid $\left(t_{R}=14.65\right.$ min), deriving from cochineal dye. Furthermore, the presence of brasilein $\left(t_{R}=16.22 \mathrm{~min}\right)$ from brazilwood dye was also identified. Type $\mathrm{C}$ compound $\left(\mathrm{t}_{\mathrm{R}}=16.71 \mathrm{~min}\right)$ might be related to brasilein degradation products [13].

\section{Wood painting}

The microscopic analysis of a wood painting cross section revealed an unexpectedly large number of layers with varying colours and heterogeneities, Figure 7. The UV radiation and visible light observation allowed the 
Table 1

UV-Vis and MS spectra of pararosaniline, rosaniline, magenta II and neofuchsine at its corresponding retention times $\left(\mathrm{t}_{\mathrm{R}}\right)$ [12].
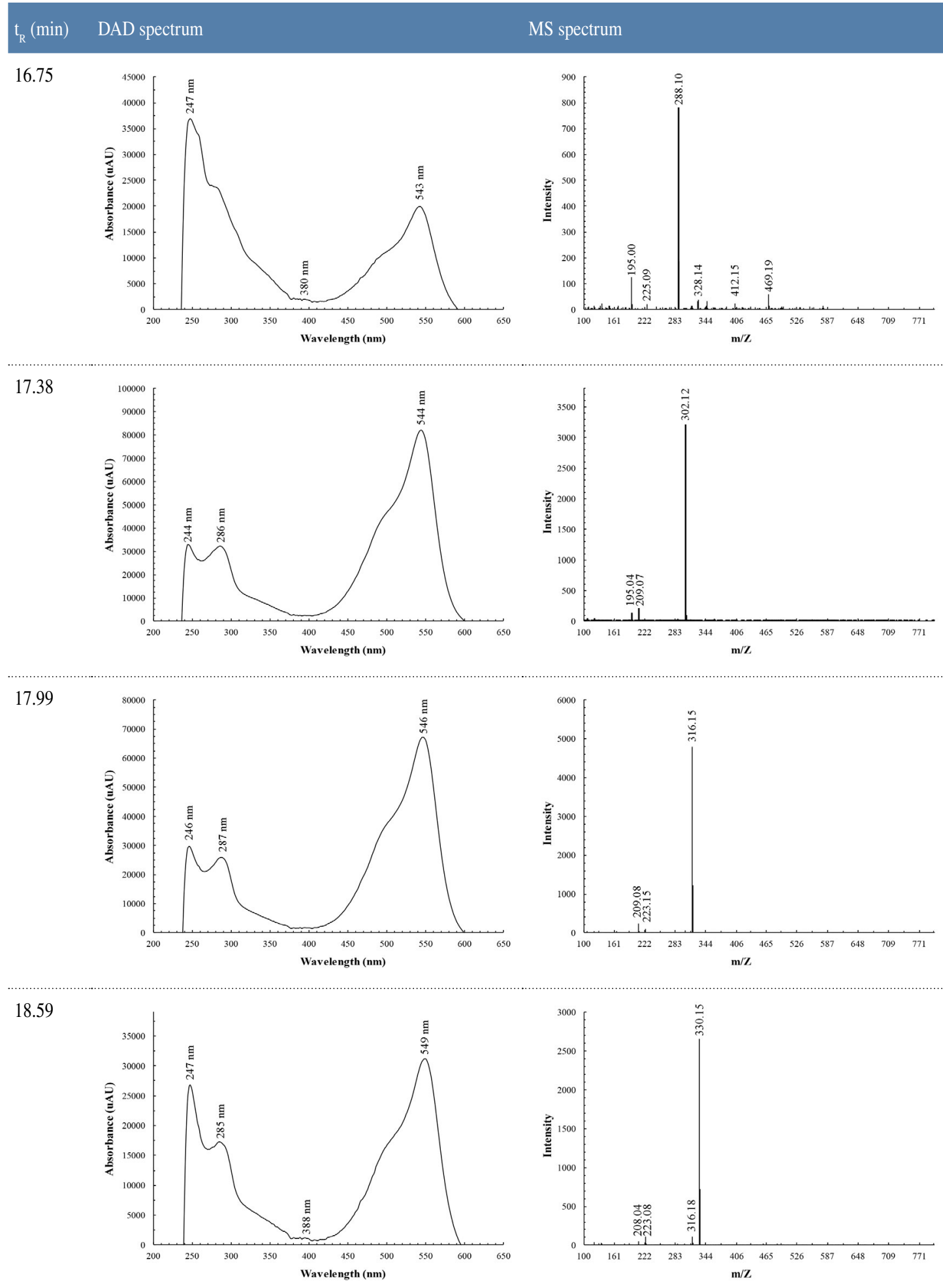

Pararosaniline

Rosaniline

Magenta II

Neofuchsine

identification of three coloured sections (sections a, $\mathrm{b}$ and $\mathrm{c}$ ), separated by a more fluorescent layer (layers 5 and 8), that was confirmed as proteinaceous glue by FTIR-ATR. It is possible that these glue layers were applied as a consolidant during previous interventions on the sedan chair. The comparison of both layers (layer
5, circa $15 \mu \mathrm{m}$; layer 8 , circa $50 \mu \mathrm{m})$ suggests that the last intervention on the sedan chair (section $\mathrm{c}$ ) required a more effective consolidation.

Apart from the two proteinaceous layers described above, an animal glue layer (layer 1) was also identified, applied over the wood surface. It is well known that the 


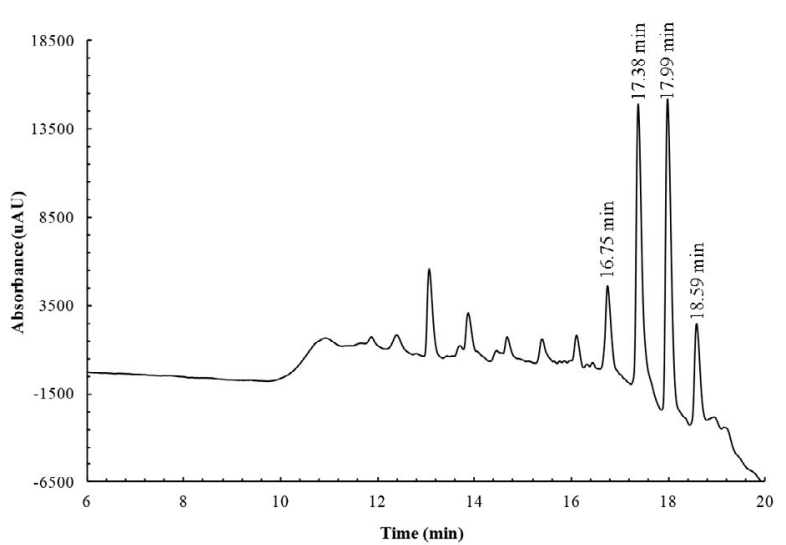

Figure 5. Total scan DAD chromatogram of sample 1.

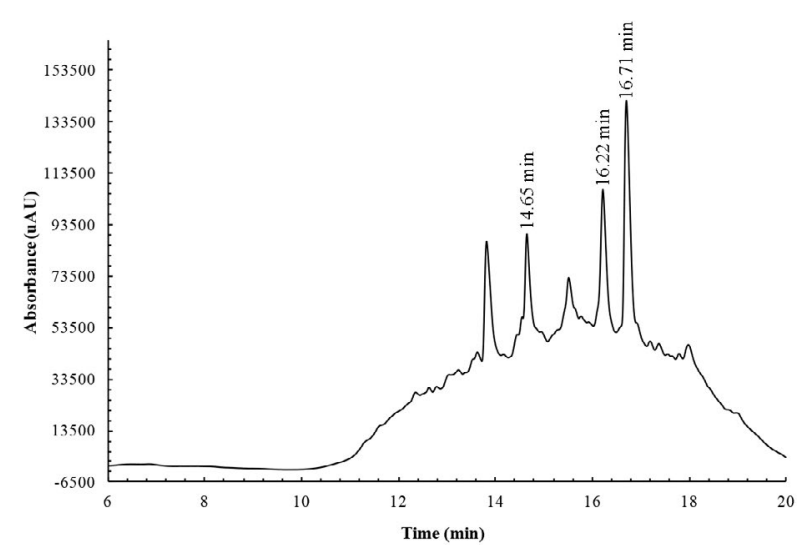

Figure 6. Total scan DAD chromatogram of sample 2.

Table 2

UV-Vis and MS spectra of carminic acid, brasilein and type C compound with its corresponding retention times $\left(\mathrm{t}_{\mathrm{R}}\right)$ [13].
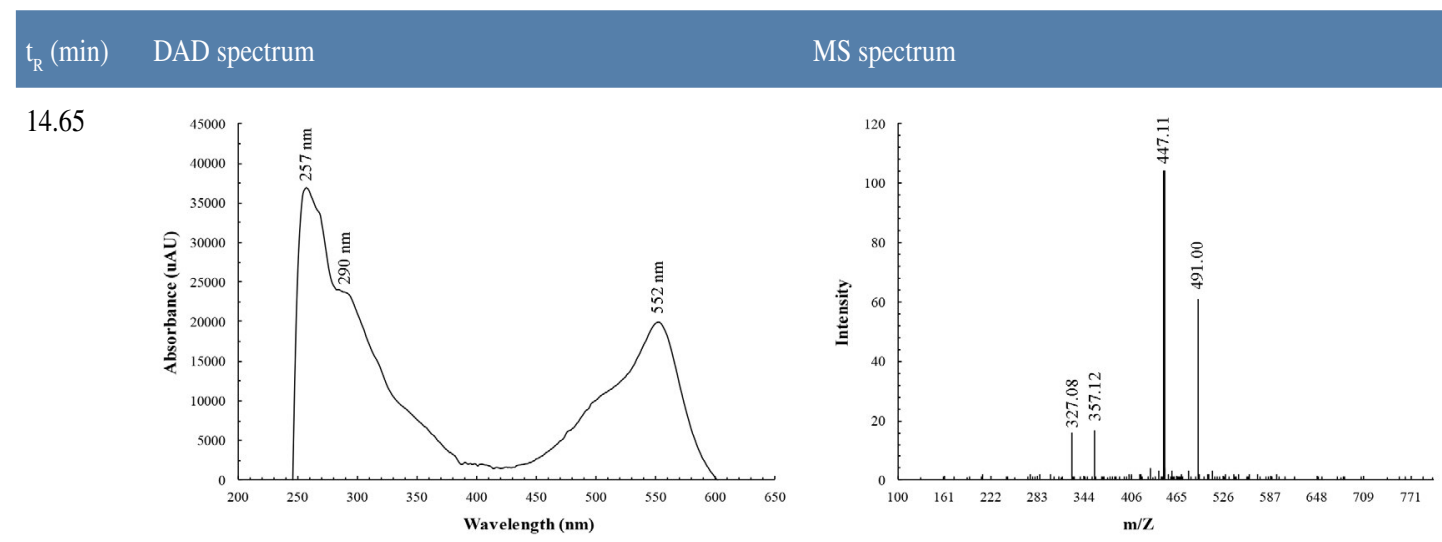

16.22
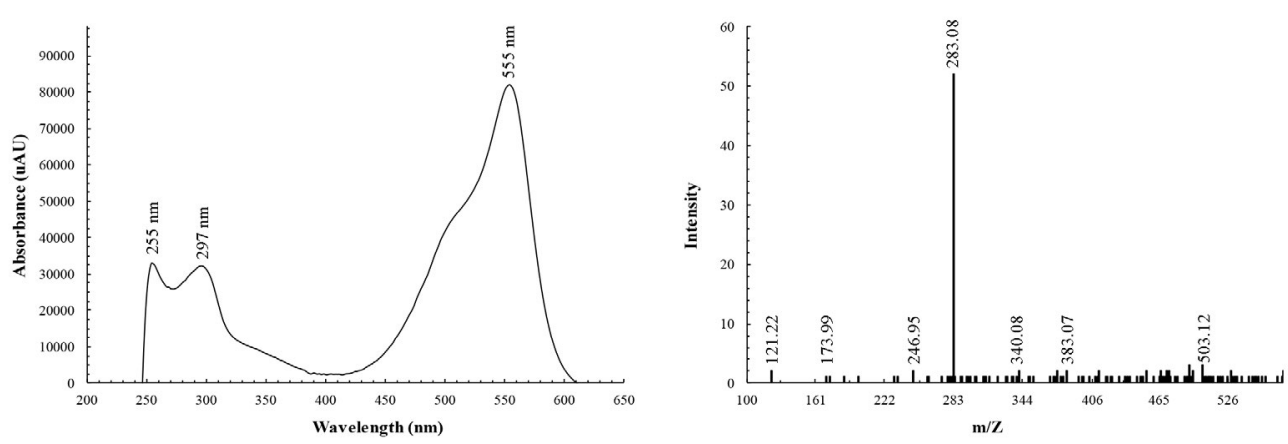

16.71
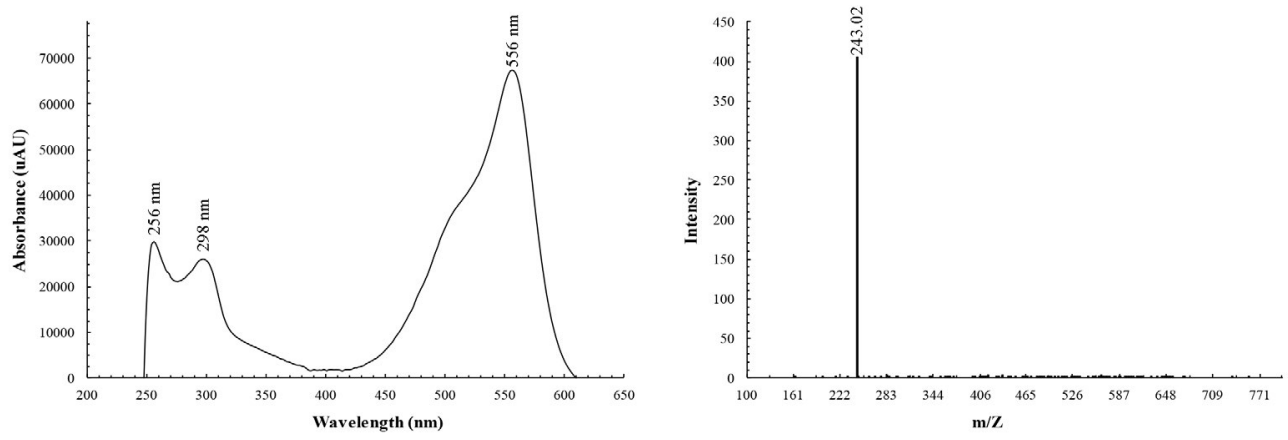

Type $\mathrm{C}$ compound 


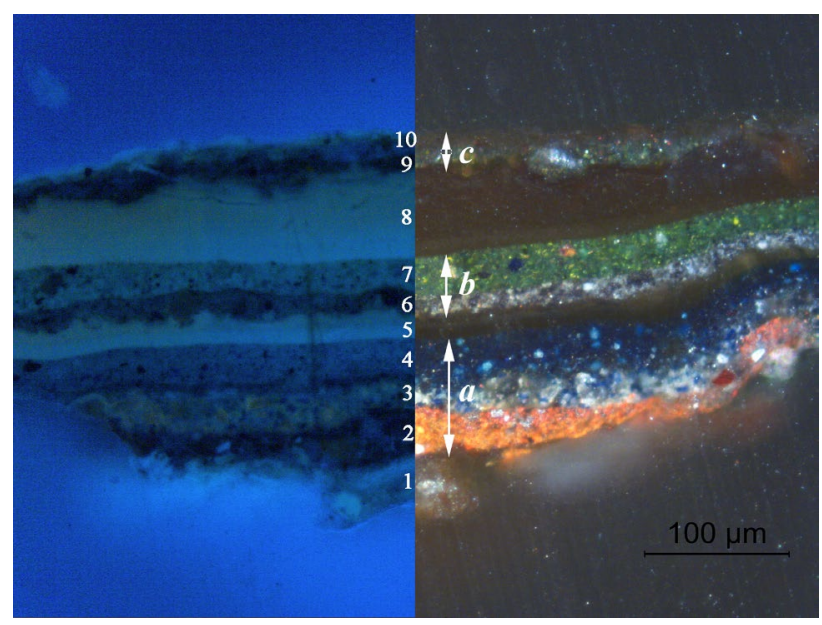

Figure 7. Optical microscopy image of a cross section of the sedan chair. Left, UV radiation; right, visible light.

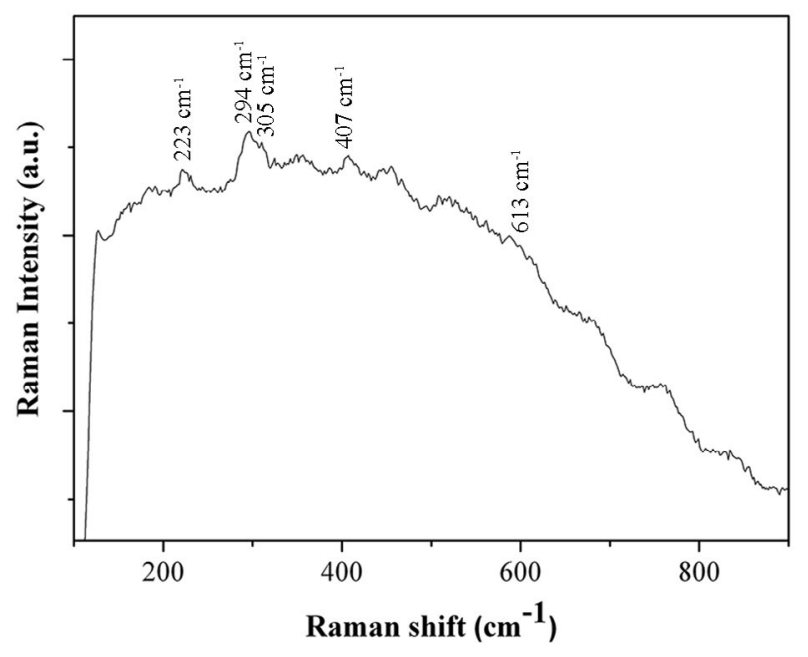

Figure 8. Raman spectrum of layer 2, with the characteristic Raman bands of hematite at 225, 293, 305, 407 and $613 \mathrm{~cm}^{-1}$ [14]).

production of wood paintings usually started by applying a layer of animal glue as a sealant to avoid absorption of the chromatic layers into the wood, which justifies the identified layer 1 in the cross-section composition.

\section{Section a}

This section comprises three layers of different colours: an orange ground layer (layer 2), an intermediate light blue layer (layer 3) and an intense blue layer (layer 4) that might correspond to the original colour of the sedan chair, Figure 7. Raman microscopy analysis of layer 2 displayed the characteristic Raman bands of hematite (namely the bands at 223, 294, 305, 407 and $613 \mathrm{~cm}^{-1}$ [14]), Figure 8.

Also, the presence of iron, silicon and aluminium, associated with hematite and aluminium silicates, was identified by SEM-EDS in layer 2, Figure 9.

A light blue layer (layer 3) was applied over layer 2. SEM-EDS analysis identified the presence of barium and lead (Figure 9), whereas FTIR imaging allowed

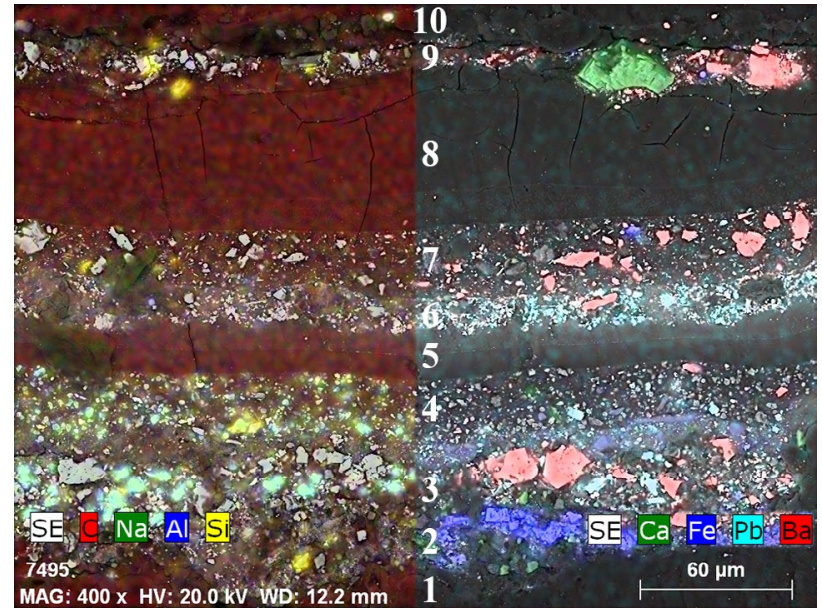

Figure 9. SEM-EDS elemental mapping of a cross section from the sedan chair.

identification of the characteristic absorption bands distribution of barite (at 1176, 1128, 1069, $982 \mathrm{~cm}^{-1}$ [15]), Figure 10. Furthermore, characteristic absorption bands at circa $1414 \mathrm{~cm}^{-1}$, pertaining to the carbonate groups of lead white, as well as absorption bands at 2931, 2856 and $1720 \mathrm{~cm}^{-1}$ that might be associated with the presence of an oxidized oil $[15,16]$.

A Prussian blue-based layer mixed with barite on an oil matrix (layer 4) was applied over layer 3. This was identified by the characteristic cyanide infrared absorption band at $2092 \mathrm{~cm}^{-1}$ [15] - Figure 10; together with presence of iron, which was determined by SEM-EDS (Figure 9).

\section{Section $b$}

This section comprises of two layers of different colours: a ground grey layer (layer 6) and an intense green layer (layer 7) that might correspond to the colour of the sedan chair, acquired after the first restoration intervention, Figure 7. Complimentary SEM-EDS, FTIR imaging and FTIR-ATR results, enabled the identification of barite and lead white on an oil matrix in layer 6. Presence of iron, sodium, silicon and aluminium in layer 7 suggests the use of a green earth pigment [8], Figures 7 and 9. Furthermore, characteristic barite and oxidized oil fingerprints were identified as well [15-16].

\section{Section c}

Although comprising the same number of layers as the previous section (two layers), this is the thickest of all three paint sections, Figure 7. SEM-EDS analysis only detected the presence of barium and calcium on layer 9 . These results combined with FTIR-ATR analysis allowed for identification of barite and calcium carbonate. It was not possible to identify the origin of the binder used on this layer, nor characterize the organic composition of layer 10 . 


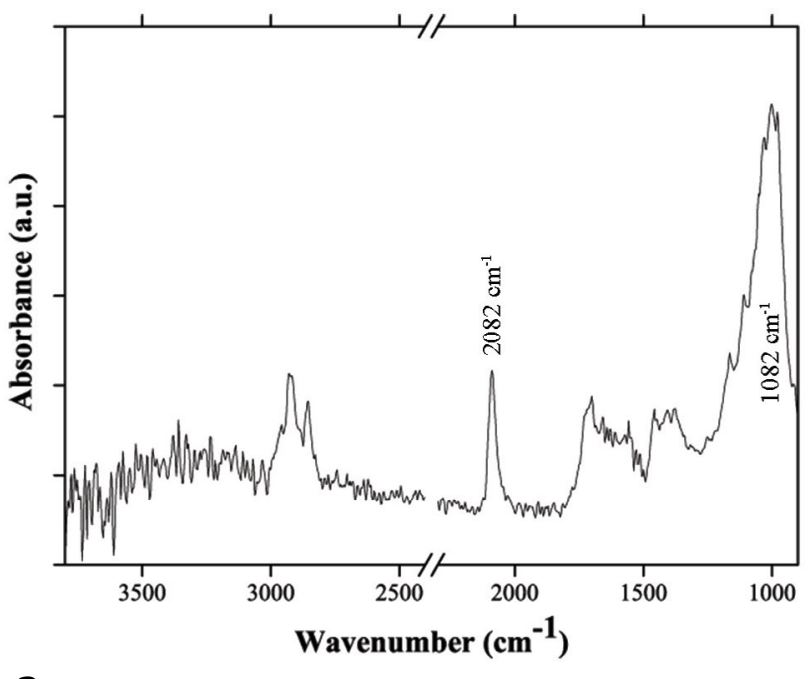

a

Figure 10. FTIR imaging results of a cross section from the sedan chair, with the integration of the absorption bands at: $b$ ) $2082 \mathrm{~cm}^{-1}$ attributed to the presence of Prussian blue; c) $1082 \mathrm{~cm}^{-1}$, attributed to the presence of barite.

\section{Conclusions}

The characterization of the textiles and wood paint unveiled an unexpected variability of materials on the analysed sedan chair. Considering the function of this chair - the transport of patients to and from a hospital - we were expecting to find more resistant and less expensive textiles used in its interior. Therefore, the presence of silk, dyed with expensive dyes (such as cochineal and brazilwood) on the anchoring zone of the door trim panel was a complete surprise. On the other hand, the use of dyed wool with synthetic fuchsine for the seat cover a less expensive and more resistant textile - revealed more appropriate for the primary function of this sedan chair.

Considering the wood painting, it is interesting to notice the composition of the lighter layers (layers 3, 6 and 9): while the first two layers are composed of barite and lead white, layer 9 was produced with barite and calcium carbonate. The fact that lead white started to be replaced by other less hazardous white pigments during the 19th and 20th century, suggests that the first intervention on the sedan chair (the application of section b responsible for the change of its original blue colour) might have occurred just after the production of the sedan chair, whereas the second intervention (section c) might have occurred later on.

In fact, the quality discrepancy between the materials used for the textile production and the simple colour and materials of the sedan chair, suggest that this sedan was initially not produced for the transport of patients, but instead for the transport of someone of a higher economic status and only afterwards adapted for its secondary function- the transport of hospital patients.
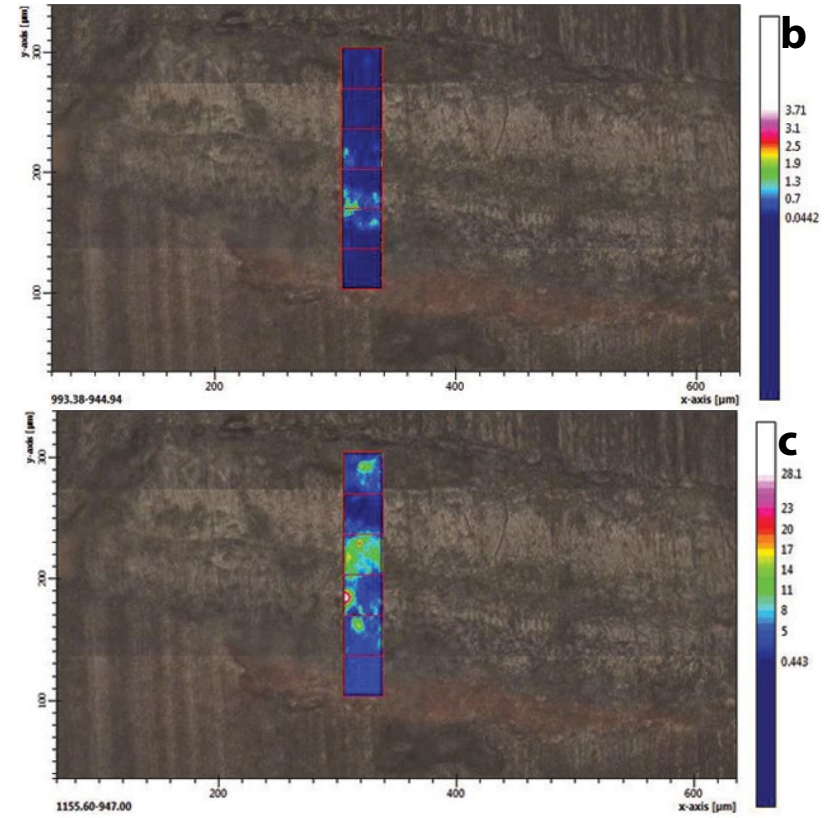

The results obtained by the analytical methods presented here, were essential for the conservation and restoration process of this sedan chair. Establishment of the intervention approaches was crucial, for the restoration of the form and function of structural elements, which was profoundly changed during previous interventions (skates and seat region), as well as understanding of decorative layers that were confused in terms of readability. By unravelling the complete stratigraphy and the nature of the preparation layers, it became possible to establish a proper future intervention strategy. Moreover, the relative thickness between layers as well as the access to sedan chair's original colour allowed students to better understand the right amount of previous retouching and partially altered layers to be removed. Choice of appropriate solvents and removal methods used in the restoration process was also based on the more or less invasive analytical information gathered. Finally, by enabling the student conservators to build a concrete mental image of the original art object and how its appearance has evolved over time, provided a critical view for them and affected their future actions/interventions. An indispensable contribution to the formation of this image was only possible by the combined interdisciplinary analytical techniques presented in this paper.

\section{Acknowledgements}

The authors would like to acknowledge Professor António Candeias, HERCULES Laboratory and other researchers involved in this work, namely Ana Manhita, Alexandra Ferreira, Margarida Nunes and Luís Dias. Catarina Miguel thanks the FCT for financial support under grant SFRH/BPD/92865/2013. 


\section{References}

1 Shephard, R. J., An Illustrated History of Health and Fitness, from Pre-History to our Post-Modern World, Springer, New York (2014).

2 Cardon, D., Natural Dyes - Sources, Tradition, Technology and Science. Archetype, London (2007).

3 Sousa, M. M.; Miguel, C.; Rodrigues, I.; Parola, A.; Pina, F.; Melo, J. S.; Melo, M. J., 'A photochemical study on the blue dye indigo: from solution to ancient Andean textiles'. Photochemical \& Photobiological Sciences 7 (2008) 13531359, doi:10.1039/b809578g.

4 Sousa, M. M.; Melo, M. J.; Parola, A. J.; Morris, P. J. T.; Rzepa, H. S.; Melo, J. S., 'A study in mauve: unveiling Perkin's dye in historic samples', Chemical European Journal 14 (2008) 8507-8513, doi:10.1002/ chem.200800718.

5 Barnett, J. C., 'Synthetic organic dyes, 1856-1901: an introductory literature review of their use and related issues in textile conservation', Reviews in Conservation 8 (2007) 67-77, doi:10.1179/sic.2007.52.Supplement-1.67.

6 Manhita, A.; Balcaen, L.; Vanhaecke, F.; Ferreira, T.; Candeias, A.; Barrocas-Dias, C., 'Unveiling the colour palette of Arraiolos carpets: material study of carpets from the 17th to 19th century period by HPLC-DAD-MS and ICP-MS', Journal of Cultural Heritage 15 (2014) 292-299, doi:10.1016/j.culher.2013.04.005.

7 Gettens, R. J.; Kühn, H.; Chase, W. T., 'Lead white', in Artists' Pigments - A Handbook of their History and Characteristics, vol. 2, ed. A. Roy, Oxford University Press, New York (1993) 67-81.

8 Eastaugh, N.; Walsh, V.; Chaplin, T.; Siddall, R., The Pigment Compendium - A Dictionary of Historical Pigments, Elsevier Butterworth-Heinemann, Burlington (2004).

9 Kirby, J., 'Paints, pigments, dyes', in Medieval Science, Technology, and Medicine - An Encyclopedia, ed. T. Glick, S. J. Livesey \& F. Wallis, Routledge, New York (2005) 379383.

10 Houck, M. M. (ed.), Identification of Textile Fibers, Elsevier, Cambridge (2009).
11 Kozlowski, R. M., Handbook of Natural Fibres: Types, Properties and Factors Affecting Breeding and Cultivation, Elsevier, Cambridge (2012).

12 Mantzouris, D.; Karapanagiotis, I.; Valianou, L.; Panayiotou, C. 'HPLC-DAD-MS analysis of dyes identified in textiles from Mount Athos', Analytical and Bioanalytical Chemistry 399(9) (2011) 3065-3079, doi:10.1007/s00216-011-4665-4.

13 Karapanagiotis, I.; Minopouloua, E.; Valianou, L.; Daniilia, S.; Chryssoulakis, Y., 'Investigation of the colourants used in icons of the Cretan School of iconography', Analytica Chimica Acta 647(2) (2009) 231-242, doi:10.1016/j. aca.2009.06.012.

14 Faria, D. L. A; Silva, S. V.; Oliveira, M. T., 'Raman microspectroscopy of some iron oxides and oxyhydroxides', Journal of Raman Spectroscopy 28 (1997) 873-878, doi:10.1002/(SICI)1097-4555(199711)28:11<873::AIDJRS177>3.0.CO;2-B.

15 Derrick, M.; Stulik, D.; Landru, J. M., Infrared Spectroscopy in Conservation, The Getty Conservation Institute, Los Angeles (1999).

16 Sotiropoulou, S.; Papliak, Z-E.; Vaccari, L., 'Micro FTIR imaging for the investigation of deteriorated organic binders in wall painting stratigraphies of different techniques and periods', Microchemical Journal 124 (2016) 559-567, doi:10.1016/j.microc.2015.10.002.

Received: 2016-01-25

Accepted: 2016-05-09

Online: 2016-07-19

This work is licensed under the Creative Commons Attribution-NonCommercial-NoDerivatives 4.0 International License. To view a copy of this license, visit http://creativecommons.org/licenses/by-nc-nd/4.0/deed.en. 